\title{
BROCCOLI (Brassica oleracea var. italica) HEAD INITIATION UNDER FIELD CONDITIONS
}

\section{*Alina Kałużewicz, Włodzimierz Krzesiński, Mikołaj Knaflewski, Jolanta Lisiecka, Tomasz Spiżewski and Barbara Frąszczak}

\author{
Department of Vegetable Crops, Poznań University of Life Sciences \\ Dąbrowskiego 159, 60-594 Poznań , Poland \\ *e-mail: kalina@up.poznan.pl
}

Received: 30.03 .2012

\begin{abstract}
A two-year study on the influence of temperature on broccoli head initiation was carried out at the "Marcelin" experimental station of the Poznan University of Life Sciences.

In each year of the study, plants were planted in the field at four dates. The evaluation of the developmental phase of the broccoli shoot apex was based on the analysis of microscope slides. The date of head initiation was assumed as the day on which the first of the examined apices were found to be at the early generative phase. The plant characteristics (number of leaves, leaf area and stem diameter) on the date of initiation were also determined.

Variation in length of the period from planting to head initiation was found both between dates of planting and between experimental years. The shortest period from planting to initiation was when the plants were planted in April and June (17-18 days) in the first year and the longest one for planting in April in the first year of the study ( 29 days). The length of the period from planting to head initiation depended on mean daily air temperature. The higher the temperature was, the shorter was the period.
\end{abstract}

Key words: Brassica oleracea var. italica, head initiation, temperature

\section{INTRODUCTION}

The transition from the vegetative to the generative phase in plants is a complex morphogenetic process. It occurs as a result of induction of flowering, which may be caused by light, temperature, water availability or chemical agents such as hormones and growth regulators (Kopcewicz and Centkow$\mathrm{sk} \mathrm{a}, 1980)$. The environmental factors are perceived by different parts of the plant. Photoperiod and irra- diance are perceived mainly by mature leaves in intact plants. Temperature is perceived by all plant parts, although low temperature (vernalisation) is often perceived mainly by the shoot apex. Water availability is perceived by the root system (B e r n i e r et al. 1993). Flower induction follows immediately after the juvenile phase in which the plant shows no sensitivity to stimuli of flowering (Ko z u m plik and Christe, 1972). The length of the juvenile phase is specific to species and variety (W i e b e, 1994).

According to Mille r et. al (1985) and W u r r et al. (1995), the main factor for the transition from the vegetative to the generative phase of broccoli plants is the temperature. According $\mathrm{M} \mathrm{ou} \mathrm{răo}$ and $\mathrm{B}$ rito (2000), at $21.5^{\circ} \mathrm{C}$ initiation occurred in broccoli after 32 days, and at $9^{\circ} \mathrm{C}$ after 88 days after planting. F e 1 low s (1997) reported that at temperatures of 5, 10, $15,20^{\circ} \mathrm{C}$ initiation occurred successively after 96,51 , 36 and 64 days. F u j i me et al. (1988) found that the vernalisation effect of temperature also depends on the length of the day. According to these authors, effectiveness of lower temperatures is higher at 16 hours of the day than at 8 hours. The aim of this study was to determine the effect of temperature on broccoli head initiation when grown at four planting dates in two consecutive years in the field. This paper is an extension of a previously published study of the first author (K ał u̇ ż w ic z et al. 2002).

\section{MATERIALS AND METHODS}

The experiment was carried out in two successive years at the "Marcelin" Experimental Station of the Poznan University of Life Sciences. The study 
comprised one cultivar of broccoli - 'Fiesta'. Transplants were planted out in the field at four dates (21 April, 10 May, 12 June, and 9 July in 1997 as well as 8 April, 12 May, 19 June, and 21 July in 1998). The trial was established in a randomised block design with four replications. In each plot, one hundred transplants were planted at the 4-leaf stage at a spacing of $0.5 \times 0.5 \mathrm{~m}$.

The experiment was established on podzolic soil; the plough layer was loamy sand underlying sandy loam. The soil was tested before planting and $100 \mathrm{~kg} \times \mathrm{ha}^{-1}$ of $\mathrm{P}_{2} \mathrm{O}_{5}, 200-250 \mathrm{~kg} \times \mathrm{ha}^{-1}$ of $\mathrm{K}_{2} \mathrm{O}$ and $60 \mathrm{~kg} \cdot \mathrm{ha}^{-1}$ of nitrogen were applied before soil prepara-

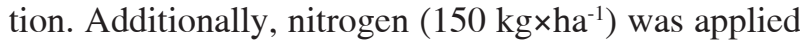
in three doses during the growing season. Plants were watered when the soil water potential had exceeded $-0.04 \mathrm{MPa}$.

From the first week after planting until the time when a head of about $1 \mathrm{~mm}$ in diameter was observed, every 3-4 days, 4-8 apices were collected in order to estimate their stage of development. The obtained microscopic slides were subjected to histological assessment. The date of head initiation was assumed as the day on which the first of the examined apices were found to be at the early generative phase. The date of initiation was determined for each date of planting. A description of the developmental phases of broccoli apices was presented in the previous publication $(\mathrm{K} \mathrm{a}$ $\nmid$ u ż e w i z et al. 2002).

Meteorological data were obtained from the Meteorological Station located 2 kilometers from the Experimental Station. The sum of day-degrees was calculated from the base temperature of $0^{\circ} \mathrm{C}$.

\section{RESULTS AND DISCUSSION}

In both years, of the study found large variations in length of the period from planting to broccoli head initiation between the dates of planting were found (Table 1). These results are contrary to the results of our previous study ( $\mathrm{K} \mathrm{ałużewicz}$ et al. 2002) in which the duration from planting to head initiation was the same at each date of planting.

The biggest differences between years in the duration of the period from planting to head initiation were in the case of the April date of planting, while this duration was the shortest for the May date of planting.

The time to head initiation depended on mean daily air temperature - the higher it was, the shorter the time to head initiation was (Fig. 1). A remarkable variety in the time from planting to head initiation was also confirmed by Grevsen and Olesen (1999). These authors conducted a field experiment in which they used three cultivars with different growing periods. The plants were planted in three consecutive years and at four dates every year. Initiation time was considered to be the day when the head diameter was $0.6 \mathrm{~mm}$. For the earliest cultivar, the time from planting to initiation was from 14 to 43 days, for the latest one - from 19 to 49 days. For all the cultivars, the longest time from planting to initiation was observed at the earliest planting date.

In our study, the plants planted at the earliest date had the lowest number of leaves as well as the smallest leaf area and stem diameter on the date of head initiation (Table 2). The later the date of planting was, the higher the values of the above features were. Significant correlation coefficients were observed between the sum of day-degrees, mean daily temperature, number of leaves and leaf area on the day of head initiation (Table 3). The correlation coefficient between the sum of day-degrees and stem diameter was also highly significant. However, the correlation coefficient between mean daily temperature and stem diameter was insignificant.

Moreover, it was observed in our study that temperature sum during the time from planting to initiation was the lowest when the plants were planted in April in the first year of the study and the highest when they were planted in July in the first year of the study (Table 4). Such a variation in temperature sum in the time from planting to initiation may be related to the reaction of broccoli to different temperature ranges. According to Fellow s et al. (1997), Whe e ler et al. (1995), W u rr et al. (1995) as well as Grevse n and Ole s e $n$ (1999), the optimum temperature for head initiation in broccoli is $15-16^{\circ} \mathrm{C}$, whereas above $22^{\circ} \mathrm{C}$ it does not occur and plants remain in the vegetative development phase (Gauss and Taylor, 1969). Effectiveness of initiation temperature depends on the phase in which it is applied. According to F o n te s et al. (1967), broccoli head initiation did not occur when low temperature $\left(4.4^{\circ} \mathrm{C}\right)$ was used for three-week-old plants. When four-week-old plants were cooled, initiation was observed in 22-25\% of plants, depending on the cultivar. Initiation occurred in all plants when low temperature was applied to five-week-old plants. The above-mentioned authors reported that devernalisation could be observed in broccoli. F o n te s et al. (1967) proved that moving plants to temperature of $22-26^{\circ} \mathrm{C}$ after exposure to low temperatures eliminated the effects of their application. This can explain the differences in the time from planting to initiation. Under field conditions, there is considerable variation in temperature, especially between day and night. Therefore, it is difficult to determine how long the plants must be subjected to low temperatures for vernalisation to occur, as well as how long high temperature must operate to eliminate the effect. 
Broccoli is believed to have a juvenile phase (W a r n e, 1961; W i e b e, 1989). During this period, it is not possible to induce head initiation even under optimum temperature conditions. It is very difficult to determine the end of the juvenile phase, because so far researchers have not found the growth features making it possible to say that broccoli plants have finished the juvenile phase. Some researchers have tried to determine the end of the juvenile phase for cauliflower but their results differed. According to A dity a and Fordh a m (1995), the juvenile phase in cauliflower may finish at the 7-9 leaf stage, while $\mathrm{Wurr}$ and Fe 11 ow s (2000) claim that it ends when plants have 10-22 leaves, depending on the cultivar.

Table 1.

Number of days from planting to head initiation in cv. 'Fiesta' broccoli planted at four planting dates in two successive years

\begin{tabular}{ccccc}
\hline \multirow{2}{*}{ Year } & \multicolumn{4}{c}{ Number of days from planting to head initiation } \\
\cline { 2 - 5 } & April & May & June & July \\
\hline 1997 & 17 & 26 & 18 & 26 \\
1998 & 29 & 25 & 24 & 21 \\
\hline
\end{tabular}

Table 2.

Characteristics of cv. 'Fiesta' broccoli plants at the day of head initiation

\begin{tabular}{|c|c|c|c|c|c|c|}
\hline \multirow{2}{*}{ Character } & \multirow{2}{*}{ Year } & \multicolumn{4}{|c|}{ Date of planting } & \multirow{2}{*}{ Mean } \\
\hline & & April & May & June & July & \\
\hline \multirow{3}{*}{$\begin{array}{c}\text { Number of leaves } \\
\text { [pcs.] }\end{array}$} & 1997 & $7.0 \mathrm{~d}^{*}$ & $10.7 \mathrm{~b}$ & $10.1 \mathrm{bc}$ & $12.4 \mathrm{a}$ & $10.1 \mathrm{a}$ \\
\hline & 1998 & $9.8 \mathrm{c}$ & $9.8 \mathrm{c}$ & $9.9 \mathrm{c}$ & $9.6 \mathrm{c}$ & $9.8 \mathrm{a}$ \\
\hline & Mean & $8.4 \mathrm{c}$ & $11.3 \mathrm{~b}$ & $10.0 \mathrm{~b}$ & $11.0 \mathrm{a}$ & \\
\hline \multirow{3}{*}{ Stem diameter [mm] } & 1997 & $6.4 \mathrm{~d}$ & $7.9 \mathrm{~d}$ & $11.0 \mathrm{bc}$ & $14.0 \mathrm{a}$ & $9.8 \mathrm{a}$ \\
\hline & 1998 & $7.6 \mathrm{~d}$ & $10.3 \mathrm{c}$ & $14.3 \mathrm{a}$ & $11.9 \mathrm{~b}$ & $11.0 \mathrm{~b}$ \\
\hline & Mean & $7.0 \mathrm{c}$ & $9.1 \mathrm{~b}$ & $12.7 \mathrm{a}$ & $13.0 \mathrm{a}$ & \\
\hline \multirow{3}{*}{ Leaf area $\left[\mathrm{cm}^{2}\right]$} & 1997 & $208.0 \mathrm{e}$ & $961.0 \mathrm{~cd}$ & $866.0 \mathrm{~cd}$ & $1425.0 \mathrm{~b}$ & $865.0 \mathrm{~b}$ \\
\hline & 1998 & $663.0 \mathrm{~d}$ & $2449.0 \mathrm{a}$ & $1083.0 \mathrm{c}$ & $1016.0 \mathrm{c}$ & $1302.8 \mathrm{~b}$ \\
\hline & Mean & $435.5 \mathrm{~d}$ & $1705.0 \mathrm{a}$ & $974.5 \mathrm{c}$ & $1220.5 \mathrm{~b}$ & \\
\hline
\end{tabular}

* - means followed by the same letter do not differ significantly at $\mathrm{P}=0.95$

Table 3.

Correlation coefficients between temperature and some characteristics of cv. 'Fiesta' broccoli plants at the day of head initiation

\begin{tabular}{lcc}
\cline { 2 - 3 } Character & \multicolumn{2}{c}{ Temperature $\left[{ }^{\circ} \mathrm{C}\right]$} \\
\cline { 2 - 3 } & Mean & Sum of day-degrees \\
\hline Number of leaves [pcs.] & $0.78^{* * *}$ & $0.75^{* *}$ \\
Leaf area $\left[\mathrm{cm}^{2}\right]$ & $0.73^{* *}$ & $0.85^{* *}$ \\
Stem diameter $[\mathrm{mm}]$ & 0.56 & $0.88^{* *}$ \\
\hline
\end{tabular}

** correlation coefficients (r) significant at $\mathrm{P}=0.01$

Table 4.

The sum of day-degrees from planting to head initiation in cv. 'Fiesta' broccoli planted at four planting dates in two successive years

\begin{tabular}{cccccc}
\hline \multirow{2}{*}{ Year } & \multicolumn{4}{c}{ Sum of day-degrees from planting to head initiation } & \multirow{2}{*}{ Mean } \\
\cline { 2 - 5 } & April & May & June & July & 251 \\
1997 & 129 & 336 & 257 & 371 & 332 \\
1998 & 217 & 297 & 273 & 352 & 296 \\
\hline Mean & 173 & &
\end{tabular}

* correlation coefficients (r) significant at $\mathrm{P}=0.05$ 


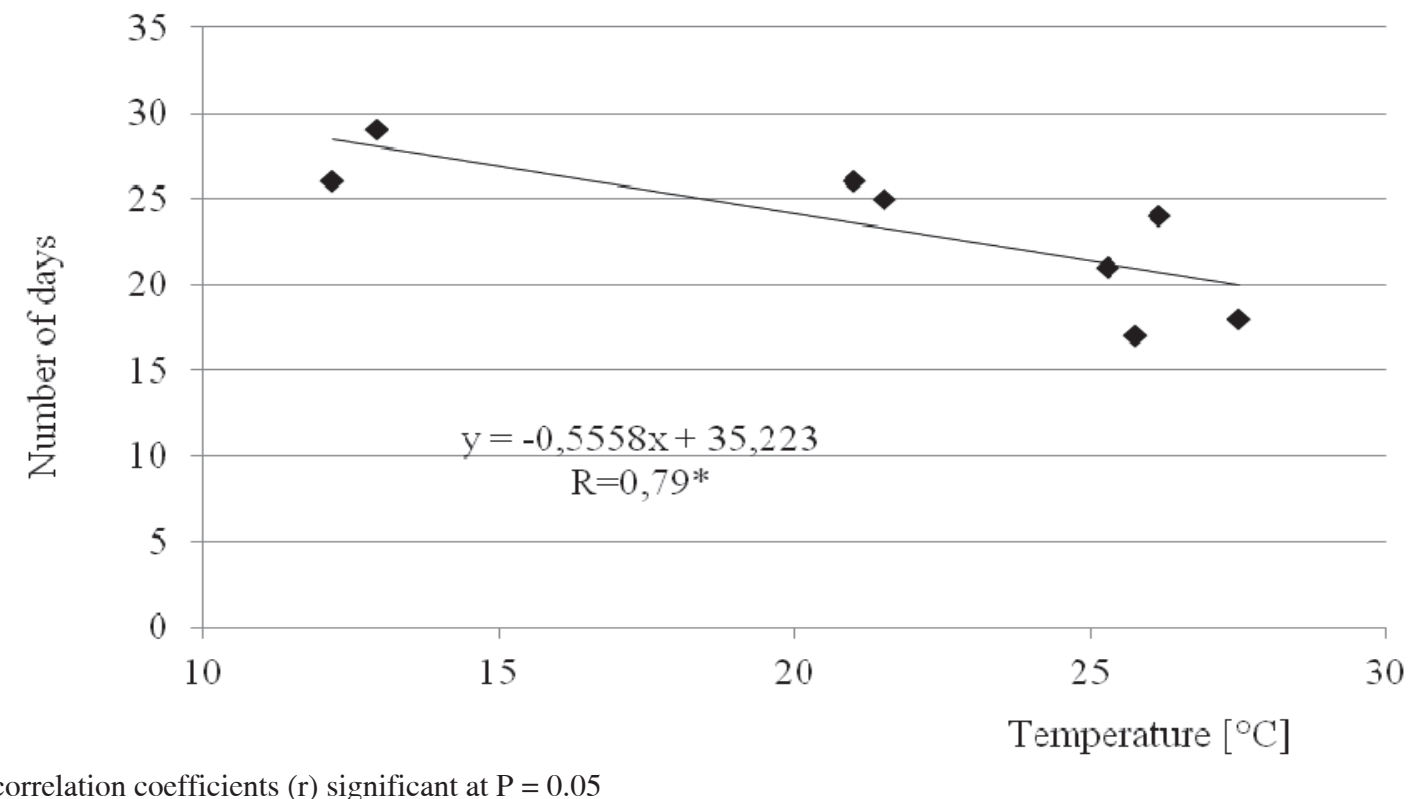

Fig. 1. Relationship between mean air temperature and number of days from planting to head initiation of cv. 'Fiesta' broccoli planted at four planting dates in two successive years

\section{CONCLUSIONS}

1. The time from planting to head initiation varied largely, even for the same date of planting.

2. During the initiation period, the plants varied in number of leaves, leaf area and stem diameter. Therefore, it is not possible to determine the phase of plant development on the basis of plant morphological characters.

3. The time from planting to broccoli head initiation depended on mean daily air temperature; the higher it was, the shorter the time was.

\section{REFERENCES}

Aditya D.K., Fordham R., 1995. Effects of cold treatment and giberellic acid on flowering of cauliflower. J. Hort. Sci. 70: 577-585.

Bernier G., Havelange A., Houssa C., Petitjean A., Lejeune P., 1993. Physiological signals that induce flowering. The Plant Cell, 5: 11471155.

Fellows J.R., Reader R. J., Wurr D.C.E., 1997. A model for leaf production and apex development in calabrese. J. Hort. Sci. 72: 327-337.

Fontes M.R., Ozbun J.L., Sadik S., 1967. Influence of temperature on initiation of floral primordia in green sprouting broccoli. Am. Soc. Hort. Sci. 91: 315-320.

Fujime Y., Saito Y., Nakayama Y., 1988. Photothermal induction of flower head formation in broccoli plants. J. Jap. Soc. Hort. Sci. 57: 70-77.

Gauss J.F., Taylor G.A., 1969. A morphological study on the time of reproductive differentiation of apical me- ristem of Brassica oleracea L. var. italica, Plenck. cv. 'Coastal'. J. Amer. Soc. Hort. Sci. 94: 105-108.

Grevsen K., Olesen J.,E., 1999. Modeling development of broccoli (Brassica oleracea L. var. italica) from transplanting to head initiation. J. Hort. Sci. Biotech. 74(6): 698-705.

Kałużewicz A., Kordakow J., Czosnowski E., $\mathrm{Kn}$ af lewski M., 2002. Effect of thermal conditions on the initiation of broccoli curd. Wydawnictwo Akademii Rolniczej we Wrocławiu, ISSN 1505-0297. EJPAU Hort. 5/2, available online

http://www.ejpau.media.pl/reries/volume5/issue2/horticulture/ art-03.html

Kopcewicz J., Centkowska G., 1980. Fizjologiczne aspekty kwitnienia roślin. / Physiological aspects of plant flowering. Wiad. Bot. 24: 269-278. (in Polish)

Kozumplik V., Christe B.R., 1972. Completion of the juvenile stage in orchardgrass. Can. J. Plant Sci. 52: 203-207.

Mourăo I. M., Brito L.M., 2000. Environmental control of plant growth development and yield in broccoli (Brassica oleracea L. var. italica Plenck): crop responses to light regime. Acta Hortic. 459: 71-79.

Miller C. H., Konsler T.R., Lamont W.J., 1985. Cold stress influence on premature flowering of broccoli. HortScience, 20: 193-195.

Warne L.G.G., 1961. Juvenile stage in cultivated forms of Brassica oleracea. Nature, 192: 889.

Wi ebe H.J., 1989. Vernalisation von wichtigen Gemüsearten-Ein überblick. Gartenbauwissenschaft, 54: 97-104. (in German)

W iebe H.L., 1994. Flower formation and timing field production of vegetables. Acta Hortic. 371: 337-343 
Wheeler T.R., Ellis R.H., Hadley P., Moris on I.L., 1995. Effects of $\mathrm{CO}_{2}$ temperature and their interaction on the growth, development and yield of cauliflower (Brassica oleracea L. botrytis). Scientia Hort. 60: 181-197.

Wurr D.C.E., Fellows J.R., Phelps K., Reader J., 1995. Vernalization in calabrese (Brassica oleracea var. italica) - a model for apex development. J. Exp. Bot. 291: 1487-1496.

Wurr D.C.E., Fellows J.R., 2000. Temperature influences on the plant development of different maturity types of cauliflower. Acta Hort. 539: 69-74.

\section{Inicjacja róż brokułu (Brassica oleracea var. italica) w warunkach polowych}

\section{Streszczenie}

W Stacji Doświadczalnej "Marcelin" Uniwersytetu Przyrodniczego w Poznaniu wykonano 2-letnie doświadczenie, którego celem było określenie wpływu temperatury na termin inicjacji róż brokułu. W każdym roku rośliny były wysadzone $\mathrm{w}$ pole $\mathrm{w}$ czterech terminach. Ocenę fazy rozwojowej wierzchołka wzrostu pędu brokułu przeprowadzono na podstawie analizy preparatów mikroskopowych. Za termin inicjacji przyjęto dzień, w którym pierwszy wierzchołek wzrostu znajdował się w fazie generatywnej wczesnej. Określono również cechy roślin $\mathrm{w}$ dniu inicjacji tj. liczbę i powierzchnię liści oraz średnicę łodygi.

Stwierdzono zróżnicowanie w długości okresu od sadzenia do inicjacji róży zarówno między terminami sadzenia, jak i między latami w danym terminie. Zanotowano najkrótszy okres od sadzenia do inicjacji gdy posadzono rośliny w kwietniu i czerwcu (17-18 dni) w pierwszym roku badań, a najdłuższy przy sadzeniu w kwietniu w drugim roku badań (29 dni). Długość okresu do inicjacji róży zależała od średniej dobowej temperatury powietrza. Im była ona wyższa, tym okres ten był krótszy. 